\title{
Biological protection of plum from shot hole disease in the humid subtropics of the Krasnodar region (Russia)
}

\author{
Nikolai Leonov*, and Timur Bulgakov \\ Federal Research Centre the Subtropical Scientific Centre of the Russian Academy of Sciences, Yana \\ Fabritsiusa street, 2/28, Sochi 354002, Russia
}

\begin{abstract}
The article considers the biologization of plum trees protection system from shot hole disease caused by the phytopathogenic fungus Wilsonomyces carpophilus in the humid subtropics of the Krasnodar region. Several biological fungicides based on different strains of the bacterium Bacillus subtilis (Alirin-B®), Bactophyt ${ }^{\circledR}$, Gamair ${ }^{\circledR}$, Phytosporin-M ${ }^{\circledR}$, Vitaplan $\left.{ }^{\circledR}\right)$, the bacterium Pseudomonas fluorescens (Rhizoplan ${ }^{\circledR}$ ) and the fungus Trichoderma harzianum (Glyocladin ${ }^{\circledR}$ and Trichocin $($ ) were tested on Stanley plum trees at the experimental base of the Federal Research Centre the Subtropical Scientific Centre of the Russian Academy of Sciences (Sochi) in 2015-2017. According to seasonal features of shot hole disease and the results of experiments, the optimal timetable schedule for plum treatment with the fungicides was found ( 3 treatments in May-June).
\end{abstract}

\section{Introduction}

Modern gardening requires the development and the application of new approaches to solving the plant protection problem. The main principle of modern agriculture is the use of knowledge-based and resource-saving technologies, which combine both high efficiency and environmental safety. Various biologics, including biofungicides, can be used as an environmentally friendly alternative to traditionally chemical pesticides $[1,2]$.

The climate of humid subtropics of the Black Sea coast of the Krasnodar region (Russia) provides to get high yields of stone fruits. However, the local climatic conditions also favor a growth and a spreading of many plant pathogens in local orchards [3]. Shot hole disease (SHD), also known as "clasterosporiosis" or "Coryneum blight", is a very harmful plum disease (along with concomitant fruit rots) caused by the phytopathogenic fungus Wilsonomyces carpophilus (Lev.) Adask., J.M. Ogawa \& E.E. Butler (the most well-known synonyms: Coryneum beyerinckii Oudem., Clasterosporium carpophilum (Lev.) Aderh., and Stigmina carpophila (Lev.) M.B. Ellis). This harmful stone fruit disease affects almost all over-ground parts of the stone fruit trees, creating the rough areas on

*Corresponding author: ozr@,vniisubtrop.ru 
fruits, causing lesions of buds and twigs, and shoots blight. However, the most noticeable damage is the holes in leaves: rounded small pieces of infected leaf tissue die and fall out because of the specific pathogen-induced necrosis. Significant disease severity can reduce the amount of photosynthesis due to the dying and the falling of infected leaves, leading to the serious tree weakening and fruit production decreasing [4].

Chemical fungicides remain a main remedy of this harmful plum disease [3, 4], but everybody knows now about the negative side effects of chemicals. For example, chemical fungicides can accumulate in plants and soil, making them toxic; frequent and excessive application of chemical fungicides could lead to the emergence of fungicide resistance in pathogens; in addition, chemical fungicides usually inhibit the growth of other microorganisms, including natural antagonists of many plant pathogens [5].

The way to reduce a pesticide load on fruit crops, including plums, is the replacing of chemical fungicides by biofungicides created on the base of bacteria and saprotrophic fungi, whose metabolites can inhibit plant pathogenic fungi $[6,7]$. The range of biological plant protection products, containing highly effective strains of microorganisms and their metabolites, are widely used in recent years [3,5]. Bacteria of the genera Bacillus and Pseudomonas gained wide practical use in agriculture as natural inhabitants of the rhizospheric mycobiota of crop plants and antagonists of plant pathogenic soilborne fungi [7-12]. Bacillus subtilis and Pseudomonas fluorescens are the most often used microorganisms [7-13], which are the main biocontrol agents in many currently applied biofungicides in Russia: Alirin-B ${ }^{\circledR}$, Bactophyt ${ }^{\circledR}$, Gamair ${ }^{\circledR}$, Phytosporin-M $\AA$, Vitaplan $\AA$ (Bacillus subtilis) and Rhizoplan ${ }^{\circledR}$ (Pseudomonas fluorescens). Biofungicides based on the aforementioned bacteria are recommended for crop protection in fruit gardening due to the environmental safety and wide range of suppressed fungal plant pathogens [7, 14, 15].

For a long time the application of biofungicides was restricted to the use of natural antagonistic relationships between saprotrophtic and parasitic microfungi in the soil and on the plant surfaces. Saprotrophic Trichoderma species are the antagonists of phytopathogenic fungi. They are mainly used for biocontrol of root rots as typical soil saprophytes, having a wide spectrum of antifungal activity [8, 14]. Trichoderma-based biofungicides also stimulate the growth and development of plants, improving water and gas exchanges in the soil, and, as a result, increasing the content of carbohydrates and proteins in plants $[14,15]$. The degradation of plant residues by Trichoderma species improves the soil structure, increases the soil fertility, and saturates it with beneficial mycobiota, providing better conditions for the growth and development of plants and for the increasing of their resistance to phytopathogens [14-16]. A whole line of biofungicides based on Trichoderma species are widely used in Russia for treat of any plant residues and soil, such as Glyocladin ${ }^{\circledR}$ and Trichocin $\AA$, which was created on the base of the fungus Trichoderma harzianum [14-16].

Due to the applicability of the biological protection methods in the control of stone fruit tree diseases, we set the goal to assess the possible prospects of SHD biocontrol on plum trees in the humid subtropics of the Black Sea coast of the Krasnodar region by several biofungicides. The following research tasks were formulated:

- to find out the optimal timetable of the plum treatment by biofungicides and chemical fungicides - taking into account the local seasonal feature of SHD;

- to study the prospects of the above-mentioned bacterial biofungicides (Alirin- $\mathrm{R}$, Bactophyt ${ }^{\circledR}$, Gamair $\AA$, Phytosporin-M ${ }^{\circledR}$, Rhizoplan $\AA$, and Vitaplan ${ }^{\circledR}$ ) and fungal biofungicides (Glyocladin ${ }^{\circledR}$ and Trichocin ${ }^{\circledR}$ ) in the projected biocontrol systems.

- to evaluate the biological effectiveness of each biofungicide both in a single treatment and in the complex application with chemical fungicides. 


\section{Materials and methods}

The studies were conducted at the experimental base of the Federal Research Centre the Subtropical Scientific Centre of the Russian Academy of Sciences (Russia, Krasnodar region, Sochi) on the plum trees ("Stanley" variety) in 2015-2017. The experimental sites were located on the distance about $1 \mathrm{~km}$ from the Black Sea coast.

The plum trees were treated with the following chemical fungicides:

- Horus ${ }^{\circledR}$ (Syngenta AG, Switzerland) - water dispersible granules; the active substance is Cyprodinil; $750 \mathrm{~g} / 1,0.3 \mathrm{~kg} / \mathrm{ha}$;

- Skor ${ }^{\circledR}$ (Syngenta AG, Switzerland) - emulsion concentrate; the active substance is Diphenoconazole; $250 \mathrm{~g} / \mathrm{l}, 0.2$ 1/ha;

- bacterial biofungicides:

- Alirin-B ${ }^{\circledR}$ (LLC PA Sibbiopharm, Russia) - liquid, the biocontrol agent is Bacillus subtilis, strain B-10, BA-10000 IU/g, titer of at least 2 billion spores/g;

- Bactophyt ${ }^{\circledR}$ (LLC PA Sibbiofarm, Russia) - wettable powder, the biocontrol agent is Bacillus subtilis, strain IPM 215, BA-10000 IU/g, titer of at least 2 billion spores/g;

- Gamair ${ }^{\circledR}$ (LLC AgroBioTehnologiya, Russia) - wettable powder, the biocontrol agent is Bacillus subtilis, strain M-22 VIZR, titer no less than $10^{11} \mathrm{CFU} / \mathrm{g}$;

- Phytosporin-M® (LLC NVP BashIncom, Russia) - liquid, the biocontrol agent is Bacillus subtilis, strain $26 \mathrm{D}$, titer of at least 100 million of living cells and spores/g;

- Rhizoplan ${ }^{\circledR}$ (LLC Agrobiotechnology, Russia) - liquid, the biocontrol agent is Pseudomonas fluorescens, strain AP-33, titer of at least $10^{10} \mathrm{CFU} / \mathrm{g}$;

- Vitaplan ${ }^{\circledR}$ (LLC AgroBioTehnologiya, Russia) - wettable powder, the biocontrol agent is Bacillus subtilis, strain VKM-B-2604D, titer $10^{10} \mathrm{CFU} / \mathrm{g}$, Bacillus subtilis strain VKM-B$2605 \mathrm{D}$, titer of at least $10^{10} \mathrm{CFU} / \mathrm{g}$;

- fungal biofungicides:

- Glyocladin ${ }^{\circledR}$ (LLC Agrobiotechnology, Russia) - liquid, the biocontrol agent is Trichoderma harzianum, strain 18 VIZR, titer of at least $10^{9} \mathrm{CFU} / \mathrm{ml}$;

- Trichocin ${ }^{\circledR}$ (LLC Agrobiotechnology, Russia) - wettable powder, the biocontrol agent is Trichoderma harzianum, strain 18 VIZR, titer of at least 1 billion CFU/ml.

The following experiment variants (groups) and the treatment timetables were taken (4fold repetition of each variant, randomized allocation of the experimental plots):

1. Control (treatment only with insecticide Phytoverm $\left.{ }^{\circledR}\right)$;

2. Standard: $\operatorname{Horus}{ }^{\circledR}(0.3 \mathrm{~kg} / \mathrm{ha})+\operatorname{Skor}{ }^{\circledR}(0.2 \mathrm{l} / \mathrm{ha})$ - standard;

3. Alirin-B ${ }^{\circledR}(2 \mathrm{l} / \mathrm{ha})+\operatorname{Horus}^{\circledR}(0.15 \mathrm{~kg} / \mathrm{ha})$; Alirin-B ${ }^{\circledR}(2 \mathrm{l} / \mathrm{ha})+\operatorname{Skor}{ }^{\circledR}(0.1 \mathrm{l} / \mathrm{ha})$;

4. Bactophyt ( $2 \mathrm{~kg} / \mathrm{ha})+$ Horus $(0.15 \mathrm{~kg} / \mathrm{ha})$; Bactophyt $(2 \mathrm{~kg} / \mathrm{ha})+\operatorname{Skor}{ }^{\circledR}(0.1 \mathrm{l} / \mathrm{ha})$;

5. Vitaplan ${ }^{\circledR}(0.12 \mathrm{~kg} / \mathrm{ha})+$ Horus ${ }^{\circledR}(0.15 \mathrm{~kg} / \mathrm{ha}) ;$ Vitaplan ${ }^{\circledR}(0.12 \mathrm{~kg} / \mathrm{ha})+\operatorname{Skor}{ }^{\circledR}(0.1 \mathrm{l} / \mathrm{ha})$;

6. Gamair ${ }^{\circledR}(0.15 \mathrm{~kg} / \mathrm{ha})+\operatorname{Horus}{ }^{\circledR}(0.15 \mathrm{~kg} / \mathrm{ha})$; Gamair ${ }^{\circledR}(0.15 \mathrm{~kg} / \mathrm{ha})+\operatorname{Skor}{ }^{\circledR}(0.1 \mathrm{l} / \mathrm{ha})$;

7. Rhizoplan ${ }^{\circledR}(5 \mathrm{l} / \mathrm{ha})+\operatorname{Horus}^{\circledR}(0.15 \mathrm{~kg} / \mathrm{ha})$; Rhizoplan ${ }^{\circledR}(5 \mathrm{l} / \mathrm{ha})+\operatorname{Skor}{ }^{\circledR}(0.1 \mathrm{l} / \mathrm{ha})$;

8. Phytosporin-M ${ }^{\circledR}\left(2\right.$ 1/ha)+Horus ${ }^{\circledR}\left(0.15\right.$ l/ha); Phytosporin-M ${ }^{\circledR}(2$ l/ha) $+\operatorname{Skor} \AA(0.1$ l/ha);

9. Glyocladin ${ }^{\circledR}(3$ l/ha $)-$ Glyocladin $®(3$ l/ The following experiment variants (groups) and the treatment timetables were taken (4-fold repetition of each variant, randomized allocation of the experimental plots):

1. Control (treatment only with insecticide Phytoverm $\left.{ }^{\circledR}\right)$;

2. Standard: Horus ${ }^{\circledR}(0.3 \mathrm{~kg} / \mathrm{ha})+\operatorname{Skor}{ }^{\circledR}(0.2 \mathrm{l} / \mathrm{ha})$ - standard;

3. Alirin-B ${ }^{\circledR}(2 \mathrm{l} / \mathrm{ha})+$ Horus ${ }^{\circledR}(0.15 \mathrm{~kg} / \mathrm{ha})$; Alirin-B ${ }^{\circledR}(2 \mathrm{l} / \mathrm{ha})+\operatorname{Skor}{ }^{\circledR}(0.1 \mathrm{l} / \mathrm{ha})$;

4. Bactophyt ( $2 \mathrm{~kg} / \mathrm{ha})+$ Horus $(0.15 \mathrm{~kg} / \mathrm{ha})$; Bactophyt $(2 \mathrm{~kg} / \mathrm{ha})+\operatorname{Skor}{ }^{\circledR}(0.1 \mathrm{l} / \mathrm{ha})$;

5. Vitaplan ${ }^{\circledR}(0.12 \mathrm{~kg} / \mathrm{ha})+$ Horus ${ }^{\circledR}(0.15 \mathrm{~kg} / \mathrm{ha})$; Vitaplan ${ }^{\circledR}(0.12 \mathrm{~kg} / \mathrm{ha})+\operatorname{Skor}{ }^{\circledR}(0.1 \mathrm{l} / \mathrm{ha})$;

6. Gamair ${ }^{\circledR}(0.15 \mathrm{~kg} / \mathrm{ha})+$ Horus ${ }^{\circledR}(0.15 \mathrm{~kg} / \mathrm{ha}) ;$ Gamair ${ }^{\circledR}(0.15 \mathrm{~kg} / \mathrm{ha})+\operatorname{Skor}{ }^{\circledR}(0.1 \mathrm{l} / \mathrm{ha})$;

7. Rhizoplan ${ }^{\circledR}(5 \mathrm{l} / \mathrm{ha})+$ Horus ${ }^{\circledR}(0.15 \mathrm{~kg} / \mathrm{ha})$; Rhizoplan ${ }^{\circledR}(5 \mathrm{l} / \mathrm{ha})+\operatorname{Skor}{ }^{\circledR}(0.1 \mathrm{l} / \mathrm{ha})$;

8. Phytosporin-M ${ }^{\circledR}\left(2\right.$ 1/ha)+Horus ${ }^{\circledR}(0.15$ l/ha $)$; Phytosporin-M ${ }^{\circledR}(2$ 1/ha $)+\operatorname{Skor}{ }^{\circledR}(0.1$ 1/ha $)$; 
9. Glyocladin $®(3 \mathrm{l} / \mathrm{ha})-$ Glyocladin $\AA(3 \mathrm{l} / \mathrm{ha})$;

10. Trichocin ${ }^{\circledR}(0.08 \mathrm{~kg} / \mathrm{ha})-\operatorname{Trichocin}{ }^{\circledR}(0.08 \mathrm{~kg} / \mathrm{ha})$.

The insecticide Phytoverm ${ }^{\circledR}$ was used to treat all experimental plum trees (including control trees) against pests (emulsion concentrate, $0.2 \mathrm{l} / \mathrm{ha}$ )., The pest treatments were carried out 3 times during the experimental period, at the phenological stages: 1) budding, 2) immediately after flowering, 3) fruit ripening, the stage "hazel". These treatments were necessary due to high crop losses from plum pests in Sochi.

The chemical fungicide Horus ${ }^{\circledR}$ (Cyprodinil) was applied for the first treatment (full rate) during a swelling of buds in the variant 2 (standard), and the chemical fungicide Skor ${ }^{\circledR}$ (Difenokonazole) was applied for the second treatment (full rate) after a flowering.

The treatments with the biofungicides were carried out in the same phenological phases in the combination with a half rate of the chemical fungicides in the variants 3-8, excluding the variants 9 and 10, where the treatments were carried out with the fungal biofungicides Glyocladin ${ }^{\circledR}$ and Trichocin ${ }^{\circledR}$ only: the first treatment - during a swelling of buds, the second one - after a flowering.

Since the fungal biofungicides (Glyocladin $\AA$ and Trichocin $($ ) are not compatible with chemical fungicides, they were used alone (without mixing with chemicals) in the abovementioned phenological phases of the plum trees. Our long-term studies [3] and the studies of other researchers $[2,3,9-16]$ confirmed that bacterial biofungicides are well compatible with chemical fungicides, because of that fact they were used together for the same plum trees treatments.

The optimal start time for protective treatments of plum trees from SHD was determined on the basis of phenological observations. [4, 17]. The most favorable time for SHD progression are the last two spring months (April and May) and in the first half of summer (June and the first half of July) in Sochi, because the weather conditions are the best for SHD in this period: a high relative air humidity (above $70 \%$ - due to frequent precipitations, mostly rainfall) combines with temperate air temperatures from +10 to $+26^{\circ} \mathrm{C}[18]$.

The disease severity of SHD was estimated for each experiment variant according to the generally accepted methods in plant pathology [19]. The biological effectiveness of each biofungicide was calculated according to the Abbot's formula [20].

The obtained data were processed by descriptive statistics methods [21] using the programs: MS Excel 2010 (v. 14.0) (Microsoft Inc. ${ }^{\circledR}$ ) and Statistica 10 (v. 10.0) (Statsoft Inc. (B). One-dimensional one-factor analysis was used to compare several independent data groups (the experiment variants) united by one attribute (the version of the treatment with the fungicides).

The least significant difference (LSD) - a value indicating the ranges of possible random deviations [21], i.e. the minimum difference between the average values of disease severity and yields - for each variant of the experience and the control was calculated. The Fisher test (F-test) was used to score the intergroup variability correlation. The null hypothesis assumed equality for the samples averages of the experiment variants [21]. If the obtained value of the F-criterion exceeded the critical value $\left(\mathrm{F}_{0}\right)$, then the null hypothesis was rejected, and the inequality of the averages was concluded. The values $\left(\mathrm{F}_{0}\right)$ were taken for a significance level $\mathrm{p}<0.05$.

\section{Results and discussion}

The weather conditions for spring and summer months had no significant deviations from the climate norm in 2015-2017 [18], and favored the intensive SHD progressing on plum trees. The maximal values of SHD severity were recorded in 2015 (Table 1) when both the high average daily air temperature and the high relative air humidity facilitated SHD 
progressing during all May and June.

Table 1. The shot hole disease (SHD) severity and the biological effectiveness of various plum tree protection schemes (the experimental base of the Federal Research Centre the Subtropical Scientific Centre of the Russian Academy of Sciences, Sochi, 2015-2017)

\begin{tabular}{|c|c|c|c|c|c|c|c|c|}
\hline \multirow[t]{2}{*}{ Variants $^{*}$} & \multicolumn{4}{|c|}{ SHD severity, $\%$} & \multicolumn{4}{|c|}{$\begin{array}{l}\text { Biological effectiveness } \\
\text { (BE), \% }\end{array}$} \\
\hline & 2015 & 2016 & 2017 & means & 2015 & 2016 & 2017 & means \\
\hline 1. Control & 24,1 & 20,0 & 12,6 & 18,9 & - & - & - & - \\
\hline $\begin{array}{l}\text { 2. Standard: } \\
\text { Skor } \AA+\text { Horus }{ }^{\circledR}\end{array}$ & 4,4 & 3,1 & 1,6 & 3,0 & 81,8 & 84,4 & 87,3 & 84,5 \\
\hline 3. Alirin-B $\mathbb{R}$ & 8,2 & 6,4 & 3,8 & 6,1 & 65,8 & 67,9 & 69,8 & 67,8 \\
\hline 4. Bactophyt ${ }^{\circledR}$ & 6,0 & 4,5 & 2,5 & 4,3 & 75,3 & 77,6 & 80,2 & 77,7 \\
\hline 5. Gamair $\AA$ & 4,2 & 2,9 & 1,5 & 2,8 & 82,7 & 85,4 & 88,1 & 85,4 \\
\hline 6. Phytosporin-M $\AA$ & 1,7 & 0,8 & 0,2 & 0,9 & 93,1 & 96,0 & 98,4 & 95,8 \\
\hline 7. Rhizoplan ${ }^{\circledR}$ & 6,1 & 5,4 & 3,2 & 4,9 & 74,5 & 76,8 & 74,6 & 75,3 \\
\hline 8. Vitaplant $\AA$ & 9,6 & 7,8 & 4,6 & 7,3 & 60,2 & 61,1 & 63,5 & 61,6 \\
\hline 9. Glyocladin $\AA$ & 2,6 & 1,6 & 0,6 & 1,6 & 89,4 & 92,2 & 95,2 & 92,3 \\
\hline 10. Trichocin ${ }^{\circledR}$ & 8,3 & 6,5 & 3,9 & 6,2 & 65,3 & 67,3 & 69,0 & 67,2 \\
\hline $\begin{array}{l}\mathrm{LSD}_{05}\left(\mathrm{~F}_{1}=134,82>\mathrm{F}_{0}=2,77\right) \\
-\left(\mathrm{F}_{1}=23,04>\mathrm{F}_{0}=2,77\right)\end{array}$ & 3,2 & 3,9 & 3,3 & - & 3,4 & 3,1 & 2,7 & - \\
\hline
\end{tabular}

Note: the experiment variant names (2-10) are abbreviated to the fungicide brand names

The first signs of SHD (reddish dots in young leaves and shoots) could be found on plum leaves in Sochi since the beginning of May, like in 2015, when SHD severity rapidly increased during May and June. However, the SHD progressing slowed significantly in July and almost stopped in August 2015 due to the high summer air temperatures and the low rainfall. The average SHD severity was recorded in 2016 and 2017, when it gradually progressed from the first decade of May to the first decade of July. The lowest average SHD severity was observed in 2017 because of dry weather in May and in the first half of June. SHD progressing on plum leaves accelerated after the heavy rainfalls in the third decade of June, and, as a result, the maximal annual SHD severity was recorded in the first decade of July 2017. However, SHD progressing stopped in later July due to the dry and hot weather in the second half of the summer.

Thus, according to our observation results, SHD severity on plum trees and its progression in each year depends on the weather (rainfall and temperature) in May, June, and July (Table 1). However, the general patterns of SHD progression remained constant every year: SHD severity on plum leaves increased quite rapidly from early May, reaching its maximum value in late June or early July, and the disease development stopped by midJuly. The highest SHD severity value $(24.1 \%)$ on the of control plum trees leaves was recorded in the rainy 2015. Both the wide range of variation (2.3) and the standard deviation index (0.68) confirms the significant variability of the SHD severity values.

The treatments with the biofungicides definitely improved the experimental trees health state compared to the control ones, and the protective effect of the chemical fungicides and the biofungicides increased in their joint application. The SHD severity on plum leaves was much lower (1.7-4.2\%) in the experiment variants, especially after the second treatment with the fungal biofungicides alone (Glyocladin ${ }^{\circledR}$ and Trichocin ${ }^{\circledR}$ ) and the second treatment with the remaining bacterial biofungicides combined with a half rate of the chemical fungicides, despite very favorable conditions for the SHD in 2015 (Table 1). The plum tree response to the treatments with the biofungicides was similar in the same periods of 2016 and 2017 when the weather was not so favorable for SHD progressing in May and 
June. Moreover, the treatments with the biofungicides produced even better results than the treatments with the chemical fungicides alone (variant 2 - standard), especially for the trees treated with Gamair ${ }^{\circledR}$, Phytosporin-M® and specifically Glyocladin ${ }^{\circledR}$ (Table 1).

The minimal SHD severity values on plum leaves were recorded under treat with Phytosporin-M ${ }^{\circledR}$ combined with a half rate of the chemical fungicides. Gamair ${ }^{\circledR}$ showed a lower protective effect compared to Phytosporin-M®. We should especially note that the treatment with Glyocladin ${ }^{\circledR}$ helped to form high and prolonged plum resistance to SHD that persisted over the next few weeks and was evidenced by the lower SHD severity in all experiment variants during a month after the last treatment with Glyocladin ${ }^{\circledR}$.

The biological effectiveness values confirmed the high resistance of the plum trees treated with the biofungicides, especially during the rapid SHD progressing in 2015. The highest SHD severity value was recorded in the control trees, whereas it was about 2.5 times lower in standard after the treatment with the chemical fungicides alone (Table 1). The lowest SHD severity was observed in the experiment variants after the treatments with the mixture of the chemical fungicides and the bacterial biofungicides (the variants 3-8), especially with Phytosporin-M®. We can interpret this fact as indirect evidence of the plant defense mechanisms activation. The similar effect was noted after the treatment with the fungal biofungicides alone (variant 9-10): the SHD severity was less in treated plum trees than in the ones treated with the chemical fungicides alone (variant $2-$ standard), even at 5 weeks after the last treatment. Thus, we have to record the obvious protective effect of the biofungicides: the induced plants resistance to SHD is still kept even a month after the last treatment. This fact is indicated by a significant SHD severity decrease in the trees treated with biofungicides compared with the trees treated with chemical fungicides only (the standard variant).

The higher yield of the plum trees treated with the biofungicides in the experiment most clearly indicates the expediency of biofungicides using. The average (over 3 years) yield was almost twice lower in control trees $(5.6 \mathrm{t} / \mathrm{ha})$ than one in the trees treated with mixtures of the chemical fungicides and the bacterial biofungicides (Table 2).

Table 2. The fungicides effects on the Stanley plum tree yields (the experimental base of the Federal Research Centre the Subtropical Scientific Centre of the Russian Academy of Sciences, Sochi,

2015-2017)

\begin{tabular}{|c|c|c|c|c|}
\hline \multirow{2}{*}{ Variants $^{*}$} & \multicolumn{4}{|c|}{ Average yield, $\mathrm{t} / \mathrm{ha}$} \\
\hline & 2015 & 2016 & 2017 & means \\
\hline 1. Control & 5,4 & 5,7 & 5,6 & 5,6 \\
\hline 2. Standard: Skor ${ }^{\circledR}+$ Horus ${ }^{\circledR}$ & 8,9 & 9,2 & 9,0 & 9,0 \\
\hline 3. Alirin-B $\mathbb{R}$ & 7,5 & 8,0 & 8,1 & 7,9 \\
\hline 4. Bactophyt ${ }^{\circledR}$ & 8,7 & 9,2 & 9,4 & 9,1 \\
\hline 5. Gamair $\AA$ & 9,8 & 10,0 & 10,2 & 10,0 \\
\hline 6. Phytosporin-M® & 9,7 & 10,9 & 11,5 & 10,7 \\
\hline 7. Rhizoplan ${ }^{\circledR}$ & 8,2 & 8,5 & 8,7 & 8,5 \\
\hline 8. Vitaplant $\AA$ & 7,0 & 6,6 & 6,0 & 6,5 \\
\hline 9. Glyocladin $\AA$ & 9,7 & 10,5 & 11,0 & 10,4 \\
\hline 10. Trichocin $\AA$ & 7,2 & 8,0 & 8,3 & 7,8 \\
\hline $\begin{array}{l}\mathrm{LSD}_{05}\left(\mathrm{~F}_{1}=29,80>\mathrm{F}_{0}=2,77\right)- \\
\left(\mathrm{F}_{1}=13,21>\mathrm{F}_{0}=2,77\right)\end{array}$ & 3,2 & 3,9 & 3,5 & - \\
\hline
\end{tabular}

The average increase in the plum yield for the 3 years in the best experimental variants was $1.1 \mathrm{t} / \mathrm{ha}$ - in comparison with the one in the standard (variant 2). The revealed differences are statistically significant $(\mathrm{p}<0.05)$. 
Thus, the biological effectiveness of the tested biofungicides was $62-96 \%$, while the effectiveness of the chemical fungicides in the standard was $82-87 \%(\mathrm{p}<0.05)$. The real preserved plum yield values reached 9.1-10.7 t/ha after treatments with the biofungicides in the different experiment variants.

\section{Conclusions}

According to the results of the research:

1. The optimal plum trees treatment timetable was revealed taking into account the local shot hole disease seasonal features. It is the period of the most rapid shot hole disease progression coinciding in time with the period from the plum tree flowering to the time of plum fruit ripening. In humid subtropics of the Black Sea coast of the Krasnodar Region this period starts from the first days of May shortly after the leaves blooming and continues until the end of June, or - if the rains fall that time - until mid-July, and ends shortly before the plum fruit ripens. A highest SHD severity usually occurs in late June or early July, depending on weather conditions of a particular year. The shot hole disease progression significantly slows down or even finishes from mid-July after an air temperature increases above $+27^{\circ} \mathrm{C}$ and a relative air humidity decreases below $65 \%$.

2. The research has shown that all tested biofungicides successfully suppress the shot hole disease on plum trees. The best statistically reliable results were achieved in the experiment variants of joint treatment with of the chemical fungicides (half rate) and the bacterial biofungicides, but both tested fungal biofungicides showed good results too. The biological effectiveness of the tested bacterial biofungicides Alirin-B ${ }^{\circledR}$, Bactophyt ${ }^{\circledR}$, Rhizoplan ${ }^{\circledR}$, Vitaplan ${ }^{\circledR}$ reached $62-78 \%$, in mixtures with a half rate of the chemical fungicides Skor ${ }^{\circledR}$ and Horus ${ }^{\circledR}$. The biological effectiveness of Gamair ${ }^{\circledR}$ and Phytosporin$M{ }^{\circledR}$ was even higher $-85-96 \%$ versus the one of the chemical fungicides $-82-87 \%$ in the standard. The average increase in the plum yield for the last 3 years amounted to 1.1 $\mathrm{t} /$ ha compared to yield of the plum trees treated with chemical fungicides only in the standard. The actual preserved plum yield values reached 9.1-10.7 t/ha after treatments with biofungicides.

3. The maximal biological effectiveness in plum tree protecting from SHD was shown by the bacterial biofungicide Phytosporin- $\mathrm{M} \AA$, in a mixture with half rate of chemical fungicides and the fungal biofungicide Glyocladin ${ }^{\circledR}$ alone. The minimal biological effectiveness was recorded for Vitaplan ${ }^{\circledR}$, in a mixture with a half rate of the chemical fungicides. The highest yield was observed after the treatment with Phytosporin-M ${ }^{\circledR}$ in mixture with a half rate of Horus ${ }^{\circledR}$ and Skor ${ }^{\circledR}$. The average yield in these experiment variants exceeded not only the control values, but also the results of the standard treatment, which we consider as a result of the effective combination of the chemical and the biological fungicides.

Thus, this research confirms the possibility of the successful biofungicides using for a plum tree protection from shot hole disease in the humid subtropics of the Black Sea coast of the Krasnodar region. The application of bacterial biofungicides in combination with chemical fungicides or fungal biofungicides alone would lower financial costs in local fruit gardening, as well as it would reduce environmental pollution with chemical pesticides.

\section{References}

1. B.B. Buchanan, W. Gruissem, R.L. Jones (ed.), Biochemistry and molecular biology of plants (John Wiley \& Sons, Chichester, West Sussex, UK), 63-67 (2015).

2. M. Stoytcheva, Pesticides in the Modern World - Pesticides Use and Management 
(In Tech, Croatia), 520 (2011)

3. N.N. Leonov, V.P. Sokirko, Applying biopreparation on stone fruits against diseases in Russian humid subtropics, Proceedings of the Kuban St. Agr. Un. 5, 125-131 (2015) https://elibrary.ru/item.asp?id=25448825

4. A. Ahmadpour, Review of shot-hole disease of stone-fruit trees, Plant Pathology Science 7(2), 1-13 (2017) https://doi.org/10.2982/PPS.7.2.1

5. S. Olson, An analysis of the biopesticide market now and where it is going, Outlooks on Pest Management 26(5), 203-206 (2015) https://doi.org/10.1564/v26_oct_04

6. D.R. Walters, A.C. Newton, G.D. Lyon (ed.). Induced resistance for plant defense: a sustainable approach to crop protection (John Wiley \& Sons, Singapoure), 258 (2014)

7. F. Mastouri, T. Bjorkman, G. Harman, Seed treatments with Trichoderma harzianum alleviate biotic, abiotic and physiological stresses in germinating seeds and seedlings. J. of Phytopathol. 100(11), 1213-1221, (2010) https://doi.org/10.1094/PHYTO-03-10-0091

8. M. Adnan, W. Islam, A. Shabbir et al., Plant defense against fungal pathogens by antagonistic fungi with Trichoderma in focus, Microbial pathogenesis 129, 7-18 (2019) https://doi.org/10.1016/j.micpath.2019.01.042

9. A. Pérez-García, D. Romero, A. De Vicente, Plant protection and growth stimulation by microorganisms: biotechnological applications of Bacilli in agriculture, Current opinion in biotechnology 22(2), 187-193 (2011) https://doi.org/10.1016/j.copbio.2010.12.003

10. G.E. Harman, Multifunctional fungal plant symbionts: new tools to enhance plant growth and productivity, New Phytologist 189(3), 647-649 (2011) https://doi.org/10.1111/j.1469-8137.2010.03614.x

11. M.A. Gordillo, M.K. Maldonado, Purification of peptides from Bacillus strains with biological activity, Chromatography and Its Applications 11, 201-225 (2012) https://doi.org/10.5772/36906

12. S. Sivasakthi, G. Usharani, P. Saranraj, Biocontrol potentiality of plant growth promoting bacteria (PGPR) - Pseudomonas fluorescens and Bacillus subtilis: A review, African J. of Agricultural Res 9(16), 1265-1277 (2014) https://doi.org/10.5897/AJAR2013.7914

13. H.B. Singh, Management of plant pathogens with microorganisms, Proceedings of the Indian National Science Academy 2, 443-454 (2014) https://doi.org/10.16943/ptinsa/2014/v80i2/55120

14. H. Saba, D. Vibhash, M. Manisha, K.S. Prashant, H. Farhan, A. Tauseef, Trichoderma - a promising plant growth stimulator and biocontrol agent, Mycosphere 3(4), 524-531 (2012) https://doi.org/10.5943/mycosphere/3/4/14

15. F. Amin, V.K., Razdan, Potential of Trichoderma species as biocontrol agents of soil borne fungal propagules, Journal of Phytology 2(10), 38-41 (2010) http://updatepublishing.com/journal/index.php/jp/article/view/2179

16. P. Sharma, V. Kumar, R. Ramesh et al., Biocontrol genes from Trichoderma species: a review, African Journal of Biotechnology 10(86), 19898-19907 (2011) https://doi.org/10.15192/PSCP.SA.2014.1.2.4045

17. G. Bubici, M. D’Amico, M. Cirulli, Field reactions of plum cultivars to the shothole disease in southern Italy, Crop protection 29(12), 1396-1400 (2010) https://doi.org/10.1016/j.cropro.2010.07.021

18. V.I. Anisimov, N.A. Bityukov, Physical geography of the resort city of Sochi: Monograph (SGUTiKD, Sochi), 291 (2008)

19. J.E. van der Plank, Plant diseases: epidemics and control (Elsevier), 366 (2013)

20. Guidelines for registration testing of fungicides in agriculture, Ed. V.I. Dolzhenko (VIZR, St. Petersburg), 378 (2009)

21. B.A. Dospekhov, Field experiment methodology (with the basics of statistical processing of research results) (Book on demand, Moscow), 352 (2012) 